\title{
Béarnais (Gascon)
}

\author{
Damien Mooney \\ Faculty of Linguistics, Philology and Phonetics, University of Oxford \\ damien.mooney@balliol.ox.ac.uk
}

The region of Béarn denotes the historically Romance-speaking part of the modern-day Pyrénées-Atlantiques département in south-western France. The langue d'oc or southern Gallo-Romance variety historically spoken in Béarn, commonly referred to as 'Béarnais', is a dialect of Gascon. This variety may also be referred to by its autoglossonym 'Biarnés' though the French term is the most widely used designation for the regional language. The number of Gascon speakers in south-western France increases steadily from north (Bordeaux) to south (the Pyrenees) and because Béarn is the area of linguistic Gascony with the highest recorded number of Gascon speakers (Moreux 2004), Béarnais may be considered the principal surviving dialect of Gascon, though other surviving dialects, such as 'Gascon de Chalosse', and 'Landais', are still spoken and written.

From the late 19th century onwards, and indeed over the course of the 20th century, Béarnais has found itself in an increasing state of language obsolescence. Language obsolescence is the process that leads to language death. It can be defined as a process occurring in a given language, currently undergoing a decline in its number of speakers, 'during which gradual reduction in use, due to domain-restriction, may result in the emergence of historically inappropriate morphological and/or phonological forms together with extensive lexical borrowing' (Jones 1998: 5-6). As the language contracts under pressure from the dominant language, linguistic changes akin to those which we would expect to find more generally in 'healthy' non-threatened languages occur at all linguistic levels. The most specific characteristic of change during language obsolescence is that it occurs in relatively large amounts and at an accelerated rate (Dorian 1981: 151).

While there is evidence to suggest that the last generation of Béarnais native speakers were born in rural areas up until the eve of the Second World War (Moreux 2004: 25), the state of the language in the latter half of the 20th century and currently into the second decade of the 21 st century displays the characteristics described by language obsolescence models: it has an age gradient of speakers with active competence decreasing as age decreases; the language is not taught to children in the home; the number of speakers is declining very rapidly, the entire population is bilingual, with French preferred in almost all situations; there is little or no literacy (Bauman 1980). In Dorian's (1981: 107) terms, Béarnais is in a situation of 'gradual death', whereby it is being lost in a contact situation, with French gradually ousting it from all domains as a subordinate minority variety.

In the entire historically Gascon-speaking region, the number of speakers, at all levels of proficiency, varies from $3 \%$ of the population in Bordeaux to $30 \%$ in Béarn, approximately 
500,000 speakers in total, with the region of Béarn attesting the most vitality in the autochthonous variety (Moreux 2004: 25). These numbers include fluent native speakers and semi-speakers. In Béarn, Moreux records $16 \%$ of people aged over 14 years as saying that they spoke Béarnais well (fluent speakers) and 14\% as saying that they spoke a little, giving a total of $30 \%$ for speakers of all levels of proficiency, or about 75,000 speakers. These results must be interpreted with caution: the number of fluent speakers is reported to be around 40,000, over half of whom are over the age of 65 years and rural-dwelling, and only $3.5 \%$ of whom are aged between 14 and 24 years.

Most of the descriptive detail in this article is based on data gathered during fieldwork carried out by the author in 2012, but at times information is taken from elsewhere to provide comparison. The transcription of the reading passage is based on the speech of an 87-year-old male speaker who was born in the town of Sedzère. The population of Sedzère was 404 in 2008 which is not substantially different from 330 in 1926, four years after the birth of the informant (INSEE 2012). The speaker has lived most of his life in the town of Nay, population 3317 in 2008 (INSEE 2012), where he worked as a second-level teacher in a Lycée Agricole.

While many other illustrations of the IPA have used younger speakers, I have chosen to use the speech of an older speaker for the following reasons: (i) Dorian (1981: 80) takes the view that the linguistic benchmark for the 'norm' in a dying language should constitute the internal conservative norm represented by the oldest local speakers; (ii) there is a nearcategorical absence of native speakers of Béarnais below the age of 65 due to the cessation of intergenerational transmission following WWII. When younger speakers do exist, they have mostly been educated in private bilingual schools, Calandretas, where the variety they have learned is called 'Occitan'. For the purpose of this illustration, I use the glossonym 'Béarnais' to indicate the southern Gallo-Romance variety which has been subjected to minimal codification and is spoken as a mother tongue by the oldest generation of speakers, native to the region. I use the name 'Occitan' to designate the codified standard language taught in Calandreta schools and used elsewhere in the limited institutional and media space afforded to regional languages in the south of France.

The orthographical conventions employed in this article are those defined by Simin Palay in the Dictionnaire du béarnais et du gascon modernes (Palay 1980). This orthographical system has been used instead of the standardised Occitan norm as, overall, it reflects local pronunciations more closely. Each of these orthographies may be used to signify a political affiliation to the Béarnais or Occitan movements respectively although such partiality is not intended here.

\section{Consonants}

The consonants of Béarnais are represented in the following table (Bouzet 1928, Bendel 1934, Grosclaude 1986, Molyneux 2002):

\begin{tabular}{|c|c|c|c|c|c|c|c|}
\hline & Bilabial & $\begin{array}{l}\text { Labio- } \\
\text { dental }\end{array}$ & Alveolar & $\begin{array}{l}\text { Post- } \\
\text { alveolar }\end{array}$ & Palatal & Velar & Glottal \\
\hline Plosive & b & & $\mathrm{t}$ & & & $\mathrm{k}$ & \\
\hline Affricate & & & & & $\overparen{\mathrm{tç}}$ & & \\
\hline Nasal & $\mathrm{m}$ & & $\mathrm{n}$ & & $\mathrm{n}$ & $\eta$ & \\
\hline Trill & & & $\mathrm{r}$ & & & & \\
\hline Tap & & & f & & & & \\
\hline Fricative & & $\mathrm{V}$ & S & (3) & & & $\mathrm{h}$ \\
\hline Approximant & & & & & $\mathrm{j}$ & $\mathrm{w}$ & \\
\hline Lateral & & & 1 & & $\kappa$ & & \\
\hline
\end{tabular}




\begin{tabular}{|c|c|c|c|c|c|c|c|c|}
\hline $\mathrm{p}$ & pés & 'weight' & $\mathrm{t}$ & tebè & 'lukewarmness' & $\mathrm{k}$ & querélhe & 'quarrel' \\
\hline \multirow[t]{3}{*}{ b } & $\begin{array}{l}\text { bés } \\
\text { [bes] }\end{array}$ & 'running water' & d & $\begin{array}{l}\text { débe } \\
\text { ['debe] }\end{array}$ & 'to have to' & g & $\begin{array}{l}\text { guespalhe } \\
\text { [ges'pa } \leqslant \text { ] }\end{array}$ & $\begin{array}{l}\text { 'swarm of } \\
\text { wasps' }\end{array}$ \\
\hline & & & & & & tç & 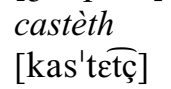 & 'castle' \\
\hline & & & & & & $\overline{\mathrm{dj}}$ & $\begin{array}{l}\text { bitàdje } \\
\text { [bi'ta⿳亠口je] }\end{array}$ & 'vineyard' \\
\hline \multirow{7}{*}{$\begin{array}{l}\mathrm{m} \\
\mathrm{f} \\
\mathrm{v}\end{array}$} & $\begin{array}{l}\text { més } \\
\text { [mes] }\end{array}$ & 'month' & $\mathrm{n}$ & $\begin{array}{l}\text { nebère } \\
\text { [ne'bero] }\end{array}$ & 'heavy snowfall' & $\mathrm{n}$ & $\begin{array}{l}\text { agnèth } \\
\text { [a'nztç] }\end{array}$ & 'lamb \\
\hline & $\begin{array}{l}\text { festî } \\
{\left[\text { fes't }^{\prime} \tilde{1}\right]}\end{array}$ & 'banquet' & $\mathrm{r}$ & $\begin{array}{l}\text { pourrét } \\
\text { [pu'ret] }\end{array}$ & 'leek' & ᄃ & $\begin{array}{l}\text { pourét } \\
\text { [pu'ret] }\end{array}$ & 'chicken' \\
\hline & $\begin{array}{l}\text { vélo } \\
\text { [ve'lo] }\end{array}$ & 'bicycle' & $\mathrm{s}$ & $\begin{array}{l}\text { sédze } \\
\text { ['sedze] }\end{array}$ & 'sixteen' & $\int$ & $\begin{array}{l}\text { chéys } \\
\text { [Sejs] }\end{array}$ & 'six’ \\
\hline & & & z & $\begin{array}{l}\text { zébre } \\
\text { ['zebro] }\end{array}$ & 'zebra' & (3) & $\begin{array}{l}j e ́ \\
{[3 \mathrm{e}]}\end{array}$ & 'yesterday' \\
\hline & & & $\mathrm{j}$ & $\begin{array}{l}y e ́ \\
{[\mathrm{je}]}\end{array}$ & 'yesterday' & W & $\begin{array}{l}\text { oéy } \\
\text { [wej] }\end{array}$ & 'today' \\
\hline & & & 1 & $\begin{array}{l}\text { lectoù } \\
\text { [lek'tu] }\end{array}$ & 'reader' & $\Lambda$ & $\begin{array}{l}\text { lhéyt } \\
\text { [Kejt] }\end{array}$ & 'bed' \\
\hline & & & $\mathrm{h}$ & $\begin{array}{l}\text { héms } \\
\text { [hems] }\end{array}$ & 'manure' & $\mathrm{y}$ & $\begin{array}{l}\text { parquing } \\
\text { [par'kin] }\end{array}$ & 'car park' \\
\hline
\end{tabular}

There is considerable variation in alternations between voiced and voiceless plosive pairs, [p b], [t d], [k g], when following nasal consonants [m] and [n] (Moreux \& Puyau 2002: 25), e.g. crampe ['krampo] or crambe ['krambo] 'bedroom', cantà [kan'ta] or candà [kan'da] 'to sing', sanc [sank] or sang [sang] 'blood'. Additionally, the voiced plosives /b d g/ have contextually conditioned allophonic variants, the approximants $[-\beta--\not \partial--\gamma-]$, when they occur intervocalically or intervocalically in a consonant cluster with [ $\mathrm{r} \mathrm{r} 1 \mathrm{z}]$.

Béarnais possesses two palatalised affricate phonemes: voiceless $/ \overline{t c ̧} /$ and voiced $/ \overline{\mathrm{dj}} /$. In masculine nouns, Latin root-final -LL- becomes /-tç/ when it occurs in coda position as a result of apocope (Grosclaude 1986: 9), e.g. CASTELLUM > castèth [kas'tetç] 'castle'. This occurs throughout Gascony, including central Béarn and Vic-Bilh (Bouzet 1928: 10). Graphic th is often called t-mouillé (literally 'palatalised t') and it is subject to high levels of geographical variation (Grosclaude 1986: 9). Latin -TC- sequences, which occurred as result of elision, such as VILLATICUM < VILLA, developed into [ $\overline{\mathrm{dj}}$ ] in Béarnais: VILLATICUM $>$ bilàdye [bi'lađje] 'village', VIATICUM > biàdye [bi'ađje] 'voyage'.

The velar nasal [y] occurs in Béarnais in borrowings from English via French, e.g. lou parquing [lu par'kin] from French le parking [lo paskin] 'the car park'. The phonemic status of $/ \mathrm{y} /$ in Béarnais is debatable but [n] regularly occurs as an allophone of $/ \mathrm{n} /$ before the velar plosives [k] and [g], e.g. sanc [sayk] 'blood', engoère [en'gwero] 'still'.

In Béarnais, the apical trill $/ \mathrm{r} /$ and apical tap $/ \mathrm{r} /$ phonemes are contrastive, e.g. pourét [pu'ret] 'chicken' vs pourrét [pu'ret] 'leek'. The distribution of [r] and [r] is somewhat constrained by their position within the syllable and with respect to word boundaries with a tendency for [r] to occur word-initially and as an onset after [n], and [r] to occur in onset clusters and in the syllable coda, but this distribution is by no means categorical (Cardaillac 1973: 32). Additionally, Béarnais rhotics are sometimes replaced by a uvular realisation [ь] which constitutes interference or transfer from French due to language contact.

Latin F became a fully aspirated glottal fricative [h] in Béarnais, e.g. Vulgar Latin FEMARIUM > héms [hems] 'manure'. Historically, Béarnais does not possess an /f/ phoneme. However, in words borrowed from French and cult words such as $f \hat{\imath}$ [f $\tilde{1}]$ ' 'end', Béarnais often retains the voiceless labiodental fricative even when a loan word has undergone 
phonological adaptation in other respects, e.g. frèse ['frezo] 'strawberry' from French fraise [ficz] 'strawberry' is commonly used. Also, Latin B and V have merged to a single phoneme, /b/, in Béarnais. Again, the voiced labiodental fricative $/ \mathrm{v} /$ is only present in Béarnais in loan words from French, e.g. vélo [ve'lo] 'bicycle' from French vélo [velo] 'bicycle', vaccî

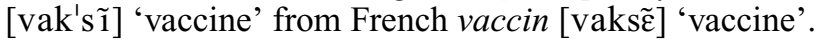

In west-central Bearn and the Pyrenean valleys and, to a lesser extent, the central Pau region, / $\mathrm{j} /$ is replaced by [3] in all positions (word-initially, intervocalically and postconsonantally), e.g. you [3u] 'me'. Where this pronunciation occurs, the orthography often changes to jou.

\section{Vowels}

Béarnais contains the following oral vowels in tonic syllables (Bouzet 1928, Bendel 1934, Grosclaude 1986. Molyneux 2002):

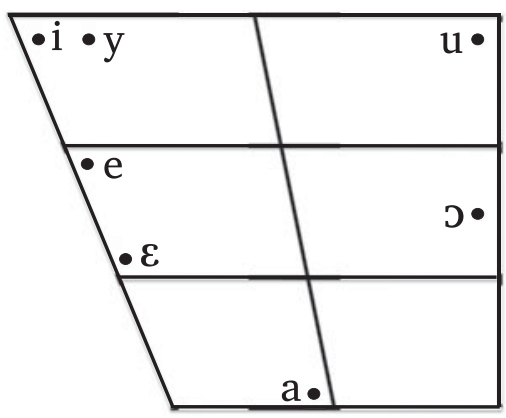

\begin{tabular}{|c|c|c|c|c|}
\hline $\begin{array}{ll}\mathrm{i} & \text { pic } \\
& \text { [pik] }\end{array}$ & 'sour' & $\mathrm{a}$ & $\begin{array}{l}p a \\
{[\mathrm{pa}]}\end{array}$ & 'pair' \\
\hline $\begin{array}{l}\text { pun } \\
\text { [pyn] }\end{array}$ & 'point' & $\mathrm{u}$ & $\begin{array}{l}\text { poume } \\
\text { ['pums] }\end{array}$ & 'apple' \\
\hline $\begin{array}{l}\text { e péch } \\
\text { [pes] }\end{array}$ & 'fish' & 0 & $\begin{array}{l}\text { porc } \\
\text { [pork] }\end{array}$ & 'pork' \\
\hline $\begin{array}{l}p \grave{e} \\
{[\mathrm{p} \varepsilon]}\end{array}$ & 'foot' & & & \\
\hline
\end{tabular}

The vowel system presented above can occur in tonic and atonic syllables. However, in atonic syllables, the contrast between $/ \mathrm{e} /$ and $/ \varepsilon /$ is neutralised and $/ \mathrm{\jmath} /$ cannot occur in pretonic syllables, where it alternates with /u/, e.g. porc [pork] 'pig' and pourquét [pur'ket] 'small pig'. The realisation of word-final post-tonic /o/ varies geographically in Béarn and has the following principal phonetic variants $[-\supset-œ-a]$, as does the realisation of word-final post-tonic /e/ with principal phonetic variants [-e -œ].

Latin root-final intervocalic -N- often drops in Béarnais in word-final position in a tonic syllable, e.g. PLANUS $>$ [plan] $>$ [plãn] $>$ plâ [plã] 'well'. This development has led to the existence of a nasal vowel system in Béarnais:

\begin{tabular}{|c|c|c|c|}
\hline $\begin{array}{ll}\tilde{1} & b \hat{\imath} \\
& {[\mathrm{b} \tilde{\mathbf{1}}]}\end{array}$ & 'wine' & $\tilde{a}$ & $\begin{array}{l}p \hat{a} \\
{[\mathrm{pã}]}\end{array}$ \\
\hline $\begin{array}{ll}\tilde{y} & \hat{u} \\
& {[\tilde{y}]}\end{array}$ & 'one' & $\tilde{\mathrm{u}}$ & $\begin{array}{l}\text { boûu } \\
\text { [bũ] }\end{array}$ \\
\hline $\begin{array}{l}h \hat{e} \\
{[\mathrm{he}]}\end{array}$ & 'hay' & & \\
\hline
\end{tabular}


Béarnais nasal vowels may alternate with VOWEL+NASAL CONSONANT sequences wordfinally but they are considered phonemic in many sub-dialects of Béarnais because they are involved in contrasts with their oral vowel counterparts, as in the following minimal pairs:

$\begin{array}{lll}/ \mathrm{i} /-/ \tilde{\mathrm{i}} / & b i[\mathrm{bi}] \text { 'to come' } & b \hat{\imath}[\mathrm{b} \tilde{\mathrm{i}}] \text { 'wine' } \\ / \mathrm{y} /-\tilde{\mathrm{y}} / & -u[\mathrm{y}] \text { 'it, to him' } & \hat{u}[\tilde{\mathrm{y}}] \text { 'one' } \\ / \mathrm{e} /-\tilde{\mathrm{e}} / & h e ́[\mathrm{he}] \text { 'he did' } & h \hat{e}[\mathrm{~h} \tilde{\mathrm{e}} \text { ' 'hay' } \\ / \mathrm{a} /-/ \tilde{\mathrm{a}} / & \text { pa }[\mathrm{pa}] \text { 'pair' } & \text { pâ }[\mathrm{p} \tilde{\mathrm{a}}] \text { 'bread' } \\ / \mathrm{u} /-/ \tilde{\mathrm{u}} / & \text { sou }[\mathrm{su}] \text { 'sun' } & \text { sôu }[\mathrm{su}] \text { 'his' }\end{array}$

In some varieties, these nasal vowels have become completely oral, thus neutralising the contrasts outlined above.

Rising and falling diphthongs are formed with a vowel and $/ \mathrm{j} /$ or $/ \mathrm{w} /$ either preceding or following. Examples are given below.

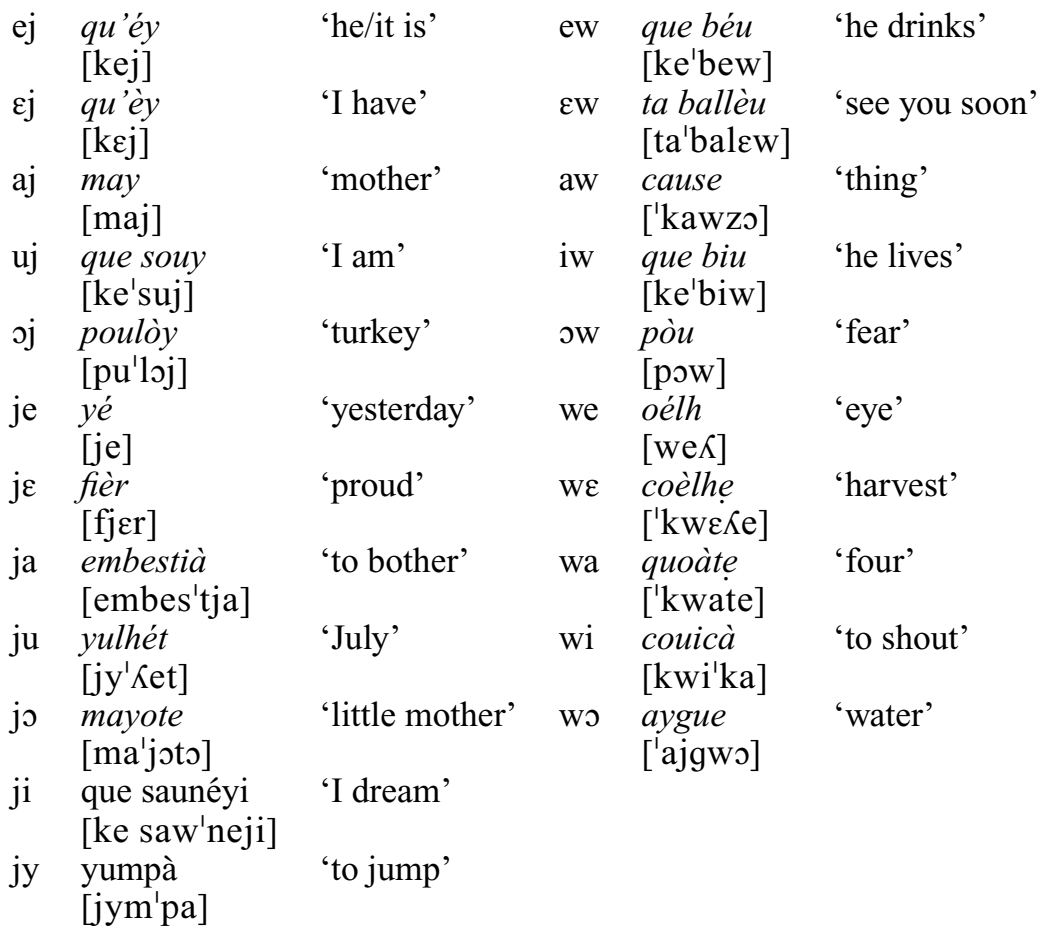

The phonetic diphthongs always begin or end with a high vocoid element. This may be interpreted as one of the independent phonemes $/ \mathrm{j} / \mathrm{or} / \mathrm{w} /$, or may be regarded as an allophonic variant of the high vowels, $/ \mathrm{i} /$ or $/ \mathrm{u} /$. The first hypothesis seems more reasonable. On the one hand, both [uj] and [wi] can occur, so that the relative prominence of the components cannot be derived from their position in the syllable. On the other hand, the possibility of having both [wi] and [iw] shows that they are commutable. Therefore, it is best to consider $/ \mathrm{j} / \mathrm{and} / \mathrm{w} / \mathrm{as}$ underlying non-syllabic elements, rather than to derive them from $/ \mathrm{i} /$ and $/ \mathrm{u} /$.

\section{Stress}

In Béarnais, and in most langue d'oc varieties more generally, the tonic syllable of lexical words may be final or penultimate. This is not the case in Nissart, whereby tonic stress may be placed on the antepenultimate syllable; proparoxytones in Nissart are equivalent to 
paroxytones in other langue d'oc varieties, e.g. DIES DOMINICA > diménegue [di'menege] 'Sunday' in Nissart and diménye [di'menje] 'Sunday' in Béarnais. The position of tonic stress on the final or penultimate syllable is subject to inter-dialectal variation, though the general pattern of tonic stress can be described as follows:

1. Stress is lexically defined for any word ending in a vowel other than [a].

2. Words ending in the vowel [a] are always oxytonous, e.g. cantà [kan'ta] 'to sing'.

3. Words ending in the post-tonic/-o/ are paroxytonous, e.g. crampe ['krampo] 'bedroom', and lexical stress is not marked in the orthography.

4. Words ended in a consonant are oxytonous, but:

(a) verbs in 3rd person plural ending in [-n] are paroxytonous, e.g. que canten [ke 'kanton] 'they sing';

(b) verbs in 2nd person singular ending in [-s] are paroxytonous in a majority of tenses, e.g. que bénes [ke 'benes] 'he/she sells';

(c) in nouns and adjectives, the plural morpheme [-s] does not modify the stress pattern found in the singular form, e.g. gouyate [gu'jato] 'young girl' and gouyates [gu'jatos] 'young girls'.

\section{Differences between dialects}

The region in which Béarnais is spoken can be divided into four main sub-dialectal areas: central (around Pau), Vic-Bilh (north-east), north and north-western Béarn (Orthez, Salies, Arthez, Arzacq) and Pyrenean valleys (Ossau, Barétous, Aspe).

Latin word-final -A became post-tonic /-o/ in the langue d'oc dialects (Bendel 1934: 28), but there is considerable geographical variation in the realisation of this phoneme. In north and north-western Béarn, the most common variant is [-œ] (Grosclaude 1986: 25), e.g. porte ['portœ] 'door'. The large central area around Pau has historically used the [-o] variant, e.g. porte ['porto] 'door'. In a very small area of the extreme eastern region of Béarn, particularly in Pontacq and Asson, on the border with the Hautes-Pyrénées département, /- $\mathrm{o} /$ is realised as [-a] (Bouzet 1928: 9), e.g. porte ['porta] 'door'. In the sound file for porte, the $/ \mathrm{f} / \mathrm{phoneme}$ is pronounced as $[\mathrm{]}$, which is phonetic transfer from French. Word-final post-tonic /-e/ is also subject to geographically-based variation. In north and north-western Béarn, /-e/ is realised as [-œ], e.g. càde ['kað̛̣] 'to fall'. Elsewhere in Béarn, [-e] is the majority variant, e.g. càde ['kað̛̣e] 'to fall'. The distinction between /-e/ and /-o/ is thus neutralised in post-tonic position in the north and north-western sub-dialect.

In north and north-western Béarn, the majority variant of /-tç/ ( $<$ Latin -LL-) is [-tç], e.g. castèth [kas'tetç] 'castle'. In central Béarn, [-t] is found, e.g. castèth [kas'tzt] 'castle' and in the Pyrenean valleys a post-alveolar affricate [- $\left.\widehat{t} \int\right]$ is more common, e.g. castèth [kas't $\left.\widehat{t} \mathrm{t}\right]$ 'castle'.

In some Pyrenean valley varieties, the contextually conditioned allophonic variants of intervocalic $\left./ \mathrm{b} \mathrm{d} \mathrm{g/,} \mathrm{namely} \mathrm{[-} \beta--{ }_{-}--\gamma-\right]$, are replaced by their corresponding voiceless plosives [p t k] when they occur before [a $ว \mathrm{y} \mathrm{u}$ ], e.g. crabe ['kra $\beta$ ] 'goat' is pronounced ['krapo].

In the north-eastern region of Vic-Bilh, many sound changes have occurred that are not attested elsewhere in Béarn. The / $\mathrm{z} /$ phoneme has become an aspirated glottal fricative [h] before the nasal consonant [n], e.g. disna [diz'na] 'to eat lunch' is pronounced [dih'na] (Moreux \& Puyau 2002: 26). Intervocalic /-d-/ is realised as [-z-] (Molyneux 2002: 27), e.g. créde ['kreơe] 'to believe' is pronounced ['kreze]. Finally, intervocalic /b/ is replaced by [-w-] (from medieval/v/), e.g. bébe ['bebe] 'to drink' is pronounced ['bewe]. 


\section{Recorded passage}

\section{Conventions}

The speaker's birthplace, Sedzère (19 km from Pau), is in the Vic-Bilh region of north-eastern Béarn but, having spent most of his life in the town of Nay (20 km from Pau) in the southcentral region, his pronunciation is characteristic of central Béarnais and does not contain any of the Vic-Bilh features outlined above.

The allophonic variants of $/ \mathrm{b} \mathrm{d} \mathrm{g/} \mathrm{in} \mathrm{intervocalic} \mathrm{position,} \mathrm{[-} \beta--\not--\gamma-]$, retain their approximant value but are transcribed below without the 'lowered' diacritic [ [ $\left.{ }^{\prime}\right]$. We may also note that this process of lenition often occurs across word boundaries, e.g. la bise [la ' $\beta$ iso] 'the north wind' in line 1. In careful speech, these allophones are often not realised, as is evident in the passage below.

Oral vowels preceding nasal consonants are nasalised throughout and are thus transcribed with the 'nasalised' diacritic [ $]$, e.g. héns [hẽns] 'in' and màntou ['mãntu] 'coat', in line 2.

Regressive assimilation of place occurs across a word boundary in lines 1-2, where quoan bedoùn /'kwan be'dun / 'when they saw' in realised as ['kwãm be'dũn].

An epenthetic glide, [j] is inserted between vowels in hiatus, e.g. qui s'y escadoùre [ki si jeska'dure] 'who suceeded in' and seré espiat [se're jes'pjat] 'would be seen', in line 3.

Realisations of $[r]$ and $[r]$ shows some evidence of contextual conditioning in the transcribed passage. There is a tendency overall for the tapped variant $[r]$ to occur as the onset of stressed syllables and the trilled variant $[\mathrm{r}]$ to occur as the onset of atonic syllables. For example, the tapped variant can be seen in sourèlh [su're $\Lambda$ ] 'sun' in lines 1, 6 and 7 while the trilled variant is present in arrayà [ara'ja] 'to shine' in line 6. This is, however, an artefact of the data and does not necessarily characterise Béarnais more generally.

\section{Transcription of recorded passage}

1 [la 'bizo e lu su'reא kes pele'jaßon | ka'dũ | aseyy'rãn 'kero lu mej hort || 'kwãm

2 be'dũn ỹ bjađja'ðu | k̃̃ nã'naßo | aru'pat 'hẽns lu sũ 'mãntu | kes 'hiken da'ßis |

3 lu pyr'me | ki si jeska'dure ẽn'taw ha ti'ra | ke se're jes'pjat kũm lu mej hort \||

4 ala'ßets | la 'bizə kes hi'ke a bu'ha ẽn si hãn a murt | mes me je $\beta u$ 'haßo | mej

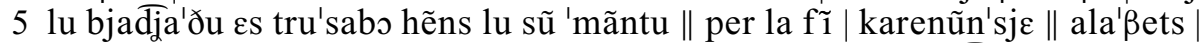

6 lu su're $\kappa$ ke ku.mẽn'se a ara'ja | e aw kap dỹ mu'mẽn | lu bjađja'ðu | $\varepsilon s k a l u^{\prime}$ rit $^{\prime}$

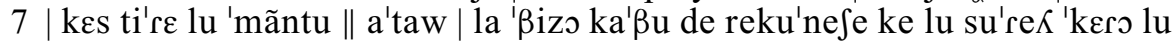

8 mej hort]

\section{Orthographic version}

1 La bise e lou sourélh que-s peleyaben, cadû asseguràn qu'ère lou méy hort. Quoan

2 bedoùn û biadyadoù qui-n anabe, arroupàt héns lou soû màntou, que-s hiquèn d'abìs :

3 lou purmè qui s'y escadoùre entà-u ha tirà, que seré espiàt coum lou méy hort.

4 Alabéts, la bise que-s hiquè à bouhà en s'y han à mourt, més méy e bouhabe, méy

5 lou biadyadoù e-s troussabe héns lou soû màntou. Per la fî, qu'arrenounciè. Alabéts,

6 lou sourélh que coumencè à arrayà e au cap d'û moumén, lou biadyadoù, escalourìt,

7 que-s tirè lou màntou. Atàu, la bise qu'aboù de recounéchẹ que lou sourélh qu'ère lou

8 méy hort.

\section{Acknowledgements}

I am grateful to Rosalind Temple and two anonymous reviewers for their helpful comments on a draft of this illustration. 


\section{References}

Bauman, James J. 1980. A guide to issues in Indian language retention. Washington, D.C.: Center for Applied Linguistics.

Bendel, Hugo. 1934. Beiträge zur Kenntnis der Mundart von Lescun (Bass.-Pyr.). Ms., Eberhard-KarlsUniversität zu Tübingen.

Bouzet, Jean. 1928. Manuel de grammaire béarnaise. Pau: Marrimpouey Jeune.

Cardaillac, Kelly R. 1973. A descriptive analysis of Gascon. The Hague \& Paris: Mouton.

Dorian, Nancy C. 1981. Language death: The life cycle of a Scottish Gaelic dialect. Philadelphia, PA: University of Philadelphia Press.

Grosclaude, Michel. 1986. La langue béarnaise et son histoire: étude sur l'évolution de l'occitan du Béarn. Orthez: Per Noste.

INSEE. 2012. Institut national de la statisitque et des études économiques. www.insee.fr (accessed March 2012).

Jones, Mari C. 1998. Language obsolescence and revitalisation: Linguistic change in two sociolinguistically contrasting Welsh communities. Oxford: Clarendon Press.

Kristol, André M. \& Jakob Th. Wüest (eds.). 1985. Drin de tot: Travaux de sociolinguistique et de dialectologie béarnaises. Berne: Peter Lang.

Molyneux, Roger-Gordon. 2002. Grammar and vocabulary of the language of Béarn: For beginners (Abridged and translated from the works of Vaspin Lespy). Monein: Prince Negue.

Moreux, Bernard. 2004. Béarnais and Gascon today: Language behaviour and perception. International Journal of the Sociology of Language 169, 25-62.

Moreux, Bernard \& Jean-Marie Puyau. 2002. Dictionnaire Français-Béarnais. Monein: Prince Negue.

Palay, Simin. 1980. Dictionnaire du béarnais et du gascon modernes (Bassin Aquitain): embrassant les dialectes du Béarn, de la Bigorre, du Gers, des Landes, et de la Gascogne maritime et garonnaise. Paris: Éditions du Centre Nationale de la Recherche Scientifique. 